\title{
IPTEKS PENGELOLAAN DANA DESA PADA DESA TUMALUNTUNG
} KECAMATAN KAUDITAN

\author{
Jullie J. Sondakh ${ }^{1}$, Grace B. Nangoi ${ }^{2}$, Novi Swandari Budiarso ${ }^{3}$ \\ ${ }^{1,2,3}$ Jurusan Akuntansi, Fakultas Ekonomi dan Bisnis, Universitas Sam Ratulangi, Jl. Kampus Bahu, Manado, \\ 95115, Indonesia \\ E-mail : julliesondakh@unsrat.ac.id
}

\begin{abstract}
Providing greater opportunities for villages to manage their own governance and equitable development implementation, with the enactment of Law Number 6 of 2014 concerning Villages, it is hoped that the village government will be more independent in managing the government and various natural resources, including financial management and wealth belonging to the village. This service aims to provide understanding to village officials about the cycle of village financial management, which starts from the planning and budgeting stages; implementation and administration; to reporting and accountability of village financial management. The specific target of this service is the making of the APB Village Implementation Realization Report and the APB Village Implementation Realization Accountability Report. In order to achieve this goal, this service uses lecture methods and technical training. Lecture to provide an initial understanding of village financial management, while technical training is training in preparing reports on the realization of village funds and accountability reports on the realization of village APB. The service plan was carried out with a preliminary survey to find out about village problems, in connection with the management of village funds, after which they conducted discussions with village leaders to collaborate, then preparation of materials and training to be presented to the village government.
\end{abstract}

Keywords: Village fund management, accountability report realization of APBDes implementation, report on the realization of village fund use.

\section{PENDAHULUAN}

Pembangunan di Indonesia merupakan pembangunan yang menganut asas berimbang, yaitu pemerataan pembangunan di kota dan di desa. Pembangunan yang berimbang mengalami permasalahan karena perbedaan sumber daya yang dimiliki kota dan desa, sehingga masih terjadi ketimpangan pembangunan antara kota dan desa. Pemerintah kemudian menerapkan strategi guna percepatan pembangunan desa, dengan membantu desa menjadi mandiri dan otonom dalam melakukan pengelolaan sumber daya yang dimiliki. Desa diberikan dana oleh pemerintah melalui Dana Desa yang merupakan dana perimbanganan, dengan tujuan penggunaan untuk penyelenggaraan pemerintah desa, pembangunan dan pemberdayaan masyarakat dan kegiatan penunjang program pemerintah.

Proses pengelolaan Alokasi Dana Desa (ADD) di desa Tumaluntung Kecamatan Kauditan, pemerintah desa dihadapkan pada kondisi tingkat pendidikan masyarakat yang rendah. Hal tersebut sesuai dengan data penduduk berdasarkan pendidikan pada tahun 2016 yaitu 95 pra sekolah, 611 SD, 411 SMP, 1250 SMA dan 183 Sarjana. Hal tersebut menunjukkan bahwa tingkat pendidikan penduduk Desa Tumaluntung masih rendah. Selain itu tingkat pemahaman perangkat desa yang masih minim mengenai pengelolaan dana desa, khususnya pada tahap pertanggungjawaban, dimana dana desa seringkali belum bisa dicairkan karena belum melaksanakan Laporan Pertanggungjawaban, masalah lainnya adalah 
belum adanya transparansi oleh pemerintah desa sebagai pengelola ADD kepada masyarakat dalam bentuk informasi penggunaan ADD.

\section{TINJAUAN PUSTAKA}

\subsection{Definisi desa}

Undang-Undang Nomor 32 tahun 2004 menyebutkan bahwa desa adalah kesatuan masyarakat dan wilayah yang memiliki wewenang mengurus dan mengatur masyarakat berdasarkan hak asal-usul dan adat istiadat setempat yang diakui dan dihormati dalam sistem pemerintahan Negara Kesatuan Republik Indonesia. Pemerintah desa merupakan unsur penyelenggara pemerintah yang dipimpin kepala desa dan dibantu perangkat desa yang terdiri atas kepala-kepala urusan, pelaksana urusan, dan kepala dusun, dalam menjalankan tugastugas pemerintahan desa. Kepala desa dan Badan Permusyawaratan Desa (BPD) memiliki wewenang membuat peraturan desa sebagai pedoman dalam mengatur pemerintahan. Sedangkan pemerintahan desa diatur berdasarkan Undang-Undang Nomor 72 Tahun 2005 tentang Desa.

Menurut Peraturan Pemerintah Nomor 72 Tahun 2005 tentang Desa, bahwa dana perimbangan keuangan pusat dan daerah yang diterima oleh kabupaten/Kota dan selanjutnya Disalurkan ke desa secara proporsional yang disebut sebagai Alokasi Dana Desa (ADD). Pengelolaan ADD menurut Peraturan Menteri Dalam Negeri Nomor 37 Tahun 2007 tentang Pedoman Pengelolaan Keuangan Desa pada pasal 20, adalah pengelolaan ADD merupakan rangkaian pengelolaan keuangan yang meliputi perencanaan, penganggaran, penatausahaan, pelaporan, pertanggungjawaban dan pengawasan keuangan desa. Tujuan adanya ADD dalam Peraturan Menteri Dalam Negeri Nomor 37 Tahun 2007 tentang Pedoman Pengelolaan Keuangan Desa, adalah: 1) Menanggulangi kemiskinan dan mengurangi kesenjangan. 2) Meningkatkan perencanaan dan penganggaran pembangunan di tingkat desa dan pemberdayaan masyarakat. 3) Meningkatkan pembangunan infrastruktur perdesaan. 4) Meningkatkan pengamalan nilai-nilai keagamaan, sosial budaya dalam rangka mewujudkan peningkatan sosial. 5) Meningkatkan ketentraman dan ketertiban masyarakat. 6) Meningkatkan pelayanan pada masyarakat desa dalam rangka pengembangan kegiatan sosial dan ekonomi masyarakat. 7) Mendorong peningkatan keswadayaan dan gotong royong masyarakat. 8)Meningkatkan pendapatan desa dan masyarakat desa melalui Badan Usaha Milik Desa (BUMDesa).

\subsection{Alokasi Dana Desa}

Dana desa merubah pola kebijakan pemerintahan kabupaten yang semula dominan dan sentralis, berubah menjadi partisipatif, responsif, dan dijalankan melalui asas desentralisasi. Alokasi dana desa merupakan bagian dari keuangan desa yang diperoleh dari bagi hasil pajak daerah dan dana perimbangan keuangan pusat dan daerah yang diterima oleh kabupaten untuk desa paling sedikit $10 \%$ (sepuluh persen). Seluruh kegiatan yang berasal dari anggaran alokasi dana desa direncanakan, dilaksanakan, dan dievaluasi secara terbuka dengan melibatkan seluruh masyarakat desa. Peraturan Menteri Dalam Negeri Nomor 113 Tahun 2014 tentang Pengelolaan Keuangan Desa, dan Undang-Undang Republik Indonesia Nomor 6 tahun 2014 tentang Desa menyebutkan bahwa Alokasi Dana Desa merupakan dana perimbangan keuangan pemerintah pusat dan daerah.

\section{METODE DAN TEKNIK PENERAPAN IPTEKS}

\subsection{Metode Penerapan Ipteks}

Metode Ipteks adalah penerapan Peraturan Menteri Dalam Negeri Nomor 37 Tahun 2007 tentang Pedoman Pengelolaan Keuangan Desa pasal 20. 


\subsection{Teknik Penerapan Ipteks}

Teknik penerapan Ipteks adalah dengan melakukan implementasi pengelolaan Alokasi Dana Desa yang meliputi pengelolaan keuangan desa yakni keseluruhan kegiatan yang meliputi perencanaan, penganggaran, penatausahaan, pelaporan, pertanggung-jawaban dan pengawasan keuangan desa.

\section{PEMBAHASAN}

\subsection{Gambaran Objek Penerapan Ipteks}

Kauditan adalah sebuah kecamatan di Kabupaten Minahasa Utara, Sulawesi Utara, Indonesia, di kecamatan ini terdapat 12 desa yaitu: Tumaluntung, Paslaten, Lembean Kaasar, Karegesan, Kaima, Treman, Kawiley, Kauditan, Watudambo, Watudambo II. Tumaluntung adalah desa tua yang peradabannya telah dimuali sejak zaman purbakala. Hal ini dibuktikan dengan adanya kuburan-kuburan tua yang disebut waruga, dan temuan lainnya berupa batu batu pahatan hasil karya para leluhur desa. Kata Tumaluntung berasal dari kata Motalengteng, merupakan nama desa mula-mula yang artinya bunyi gema air terjun. Desa Tumaluntung ini wilayahnya memanjang $11,5 \mathrm{~km}$ dari utara di kaki gunung klabat ke selatan hingga bebatasan dengan kecamatan Tondano Kabupaten Minahasa. Dari Timur berbatasan dengan desa Paslaten Kecamatan Kauditan 1,8 km sampai ke Barat berbatasan dengan kecamatan Airmadidi kecamatan Tondano Utara. Luas keseluruhan wilayah desa \pm 2400 ha. Ketinggian desa $\pm 268 \mathrm{~m}$ dari permukaan air laut. Merupakan daerah lereng dengan kemiringan rata-rata 6 derajat. Suhu udarar antara 21-31 derajat Celcius.

Keadaan demografi desa Tumaluntung dapat dilihat pada tabel 1.

\section{Tabel 1. Demografi desa Tumaluntung tahun}

\begin{tabular}{ll}
\hline Keterangan & Tahun 2016 \\
\hline Jumlah keluarga & 1106 \\
Jumlah laki-laki & 1860 \\
Jumlah perempuan & 1821 \\
\hline Total & $\mathbf{3 6 8 1}$ \\
\hline
\end{tabular}

Penyebaran penduduk perhektar wilayah pemukiman adalah 16 orang. Tingkat pendidikan masyarakat desa Tumaluntung dapat dilihat pada tabel 2

Tabel 2. Tingkat pendidikan

\begin{tabular}{lllll}
\hline Pra Sekolah & SD & SMP & SMA & Sarjana \\
\hline 95 & 611 & 411 & 1250 & 183 \\
\hline
\end{tabular}

Mata pencarian masyararat desa Tumalauntung dapat dilihat pada tabel 3

Tabel 3. Mata pencarian

\begin{tabular}{llllll}
\hline Petani & Swasta & Guru & ASN & TNI/POLRI & Jasa \\
\hline 248 & 250 & 38 & 69 & 26 & 68 \\
\hline
\end{tabular}

Masalah konflik yang dihadapi desa Tumaluntung saat ini adalah masalah pembebasan tanah yang digunakan untuk jalan tol. Pemilik lahan di desa Tumaluntung Kecamatan Kauditan masih mengeluhkan ganti rugi lahan yang sampai saat ini masih terkatung katung. Sumber listrik dan gas alternatif di desa ini dilakukan dengan membangun reaktor dengan pemanfaatan limbah ternak menjadi biogas. Dana desa telah diatur dalam Peraturan Pemerintah Nomor 60 Tahun 2014 tentang Dana Desa yang bersumber dari APBN, Pasal 1, ayat 2 : Dana Desa adalah Dana yang bersumber dari Anggaran Pendapatan dan 
Belanja Negara diberikan pada desa, melalui Anggaran Pendapatan dan Belanja Daerah Kabupaten/Kota dan digunakan untuk membiayai penyelenggaraan pemerintahan, pelaksanaan pembangunan, pembinaan kemasyarakatan, dan pemberdayaan masyarakat. Pasal 6 mengatur tentang mekanisme transfer dana desa, yaitu melalui APBD kabupaten/kota untuk selanjutnya ditransfer ke APB Desa. Adapun permasalahan mitra sehubungan dengan pengelolaan keuangan desa adalah :

\section{Regulasi dan Kelembagaan}

Program dana desa dimulai dari tahun 2015 dengan sejumlah regulasi yang mengatur pengelolaan keuangan desa belum lengkap, sehingga regulasi yang sudah ada seiring dengan perjalana waktu dan kondisi nyata pengelolaan dana desa dilapangan mengalami perubahan-perubahan dan rebisi bahkan ditetapkan regulasi baru sebagai pengganti regulasi sebelumnya. Bahkan potensi tumpang tindih kewenangan kementrian menyebabkan para pelaksanan ditingkat kabupaten terlebih oleh pengelola ditingkat desa, mengalami kesulitan dan keraguan dalam pengelolaan dana desa. Hal ini berpotensi menyebabkan penyimpangan pengelolaan dana desa yang tidak sesuai dengan ketentuanketentuan/regulasi yang ada, yang sering berubah-ubah dalam kaitannya antara Rencana Kerja Desa dengan peraturan-peraturan/regulasi di tiap desa berbeda-beda. Hal ini juga terkait keanekaragaman kondisi geografis, adat istiadat, sosial budaya masyarakat.

\section{Aspek Sumber Daya Manusia}

Pengalokasian dana untuk pembangunan desa yang disebut dengan dana desa (DD), pelaksanaannya dimulai pada tahun anggaran 2015. Dengan sejumlah regulasi yang mengatur tentang penyaluran, pertanggungjawaban dana desa, menjadikan sumber daya manusia sebagai modal penting dalam pembangunan desa (Florensi, 2014). Beragam regulasi mengenai pengelolaan dana desa membuat semakin sulit dipahami dan diimplemantasikan oleh kepala-kepala desa dengan tingkat pendidikan yang tidak memadai, sehingga dalam penyusunan Rencana Kerja Pemerintah desa dan Anggaran Pendapatan Belanja Desa menghadapi kendala menyangkut keterbatasan sumber daya manusia yang tidak kompeten. Hal ini menyebabkan penggunaan dana desa tidak maksimal.

\section{Aspek Tata Laksana}

Mekanisme dan waktu penyaluran dan pengelolaan dana desa yang sudah ditetapkan sulit dipatuhi sehingga menyebabkan keterlambatan transfer dana desa dari pusat ke kabupaten. Hal ini berdampak terhadap pelaksana program/ kegiatan pembangunan di desa, dan keterlambatan pertanggungjawaban yang dapat menggangu mekanisme secara keseluruhan. Masalah lain yang terkait dengan tata laksana adalah belum dikelola dengan baik ditingkat desa yaitu tidak adanya satuan harga baku, sehingga dalam menyusun Anggaran Pendapatan dan Belanja tidak terstandarisasi, sehingga rawan terjadi penyimpangan dan menjadi temuan aparat pemeriksa.

\section{Aspek Pengawasan}

Dari sisi pengawasan penyaluran, pengelolaan/penggunaan dan pertanggungjawaban dana desa melibatkan banyak pihak sehingga perlu adanya koordinasi antar berbagai pihak, selain itu regulasi pengawasan saat ini belum mendukung pengawasan yang efektif terhadap pengelolaan keuangan dana desa belum maksimal disebabkan karena belum ada regulasi yang jelas untuk pengawasan penggunaan dana desa.

\subsection{Pembahasan}

Tahapan pengelolaan keuangan desa tersebut diatur dalam Peraturan Menteri Dalam Negeri Nomor 113 Tahun 2014 tentang Pengelolaan Keuangan Desa, meliputi a) Perencanaan, b) Pelaksanaan c) Penatausahaan d) Pelaporan dan e) Pertanggungjawaban. Perencanaan awal dalam alokasi dana desa yang merupakan tahap paling awal dari kegiatan pengelolaan alokasi dana desa. Kegiatan perencanaan bertujuan untuk menyusun rencana 
kegiatan secara partisipatif sekaligus menetapkan alokasi anggaran yang dituangkan dalam Daftar Rencana Kegiatan (DRK). Setelah DRK tersusun, selanjutnya kepala desa selaku penanggung jawab membentuk tim pelaksana alokasi dana desa yang terdiri dari Pelaksana Teknis Pengelolaan Keuangan Desa (PTPKD) dan bendahara desa.

Pelaksanaan alokasi dana desa yang merupakan tahap realisasi dari seluruh rencana kegiatan pengelolaan alokasi dana desa yang telah disepakati. Alokasi dana desa yang diterima digunakan untuk biaya penyelenggaran pemerintah yang diserahkan pada masingmasing-masing pos dan untuk biaya pemberdayaan masyarakat diserahkan kepada tim pelaksana tingkat desa yang nantinya akan dipertanggungjawabkan kepada kepala desa. Pelaksana kegiatan tersebut meliputi kepala desa, karang taruna, tim pengerak PKK, Badan Permusyawaratan Desa (BPD), serta masyarakat desa. Keterlibatan masyarakat tidak hanya sebagai obyek dan pelaku melainkan sebagai bagian dalam nenentukan dan membuat program desa (Prabawa, 2015).

Pengawasan alokasi dana desa yang diperlukan agar pelaksanaan tugas yang telah ditetapkan terhindar dari penyimpangan-penyimpangan. Pengawasan tersebut meliputi pengawasan langsung yang dilakukan oleh kepala desa kepada para tim pelaksana pengelolaan alokasi dana desa dan pengawasan tidak langsung yang berupa laporan tertulis yaitu Surat Pertanggung Jawaban (SPJ) alokasi dana desa. Pengawasan terhadap pengelola keuangan ditingkat desa, perlu melibatkan masyarakat,namun terhalang oleh masih lemahnya aspek sumber daya manusia di desa (Azwardi dan Sukanto, 2014).

Disisi lain, pengawasan yang dilakukan oleh masyarakat desa masih belum nampak bahkan masyarakat cenderung tidak peduli dengan adanya program tersebut. Pengawasan dari masyarakat sangat diperlukan untuk menghindari terjadinya kesalahan, penyelewengan atau hal-hal lain yang tidak dinginkan. Pemerintah desa perlu memberikan akses informasi bagi masyarakat terkait penggunaan dana desa, sehingga masyarakat dapat melakukan pengawasan dan evaluasi (Rohmah dan Ma'aruf, 2016).

Pertangungjawaban alokasi dana desa yang dilakukan secara administratif dalam bentuk Surat Pertanggung Jawaban (SPJ) dengan format keuangan yang sudah ditentukan dalam peraturan yang berlaku. Pertanggungjawaban tersebut merupakan wujud dari pertanggungjawaban administratif desa kepada pemerintah di atasnya, sedangkan pertanggungjawaban pemerintah desa kepada masyarakat masih belum nampak.

Prinsip utama yang mendasari pengelolaan keuangan daerah dan prinsip good governance adalah transparansi (Haryanto 2007:106; Mardiasmo, 2002:106) di desa Tumaluntung transparansi alokasi dana desa yang hanya dilakukan dengan mengadakan pertemuan dengan perwakilan masyarakat dan lembaga-lembaga terkait yang membahas pertanggungjawaban alokasi dana desa. Sedangkan masyarakat tidak mempunyai antusiasme dengan upaya yang dilakukan pemerintah desa tersebut.

\section{KESIMPULAN}

Pengelolaan Keuangan Alokasi Dana Desa (ADD) merupakan bagian yang tidak terpisahkan dari Pengelolaan Keuangan Desa dalam APBDesa. Pengelolaan ADD meliputi tahap perencanaan dan penganggaran keuangan desa, pelaksanaan APBDesa, penatausahaan keuangan desa, pelaporan dan pertanggungjawaban keuangan desa. Desa Tumaluntung menghadapi masalah sehubungan dengan kondisi tingkat pendidikan masyarakatnya yang masih lemah. Selain itu tingkat pemahaman perangkat desa yang masih minim mengenai pengelolaan dana desa, khususnya pada tahap pertanggungjawaban, dimana dana desa seringkali belum bisa dicairkan karena belum melaksanakan Laporan Pertanggungjawaban, masalah lainnya adalah belum adanya transparansi oleh pemerintah desa sebagai pengelola ADD kepada masyarakat dalam bentuk informasi penggunaan ADD. 


\section{DAFTAR PUSTAKA}

Azwardi, dan Sukanto. 2014. Efektifitas Alokasi Dana Desa (ADD) Dan Kemiskinan Di Provinsi Sumatera Selatan. Jurnal Ekonomi Pembangunan, 12(1), 29-41.

Florensi H. 2014. Pelaksanaan Kebijakan Alokasi Dana Desa (ADD) Dalam Memberdayakan Masyarakat di Desa Cerme, Kecamatan Grogol, Kabupaten Kediri. Kebijakan dan Manajemen Publik. 2(1), 1-8.

Haryanto, Sahmuddin, dan Arifuddin, 2007. Akuntansi Sektor Publik. Edisi Pertama: Universitas Diponegoro. Semarang.

Mardiasmo. 2002, Otonomi Daerah dan Manajemen Keuangan Daerah, Andi, Yogyakarta.

Wahjudin, Sumpeno (2011) Perencanaan Desa Terpadu. Banda Aceh,Reinforcement Action and Development.

Peraturan Menteri Dalam Negeri Nomor 37 Tahun 2007 Pedoman Pengelolaan Keuangan Desa. Peraturan Pemerintah Republik Indonesia Nomor 72 Tahun 2005 tentang Desa.

Peraturan Pemerintah Nomor 72 Tahun 2005 Tentang Desa (c. 3) Jakarta

Peraturan Menteri Dalam Negeri Nomor 113 Tahun 2014 tentang Pengelolaan Keuangan Desa.

Alokasi Dana Desa dalam Pembangunan di desa Loa Lepu Kecamatan Tenggarong Seberang

Prabawa, A. 2015. Pengelolaan Alokasi Dana Desa Dalam Pembangunan Di Desa Loa Lepu Kecamatan Tenggarong Seberang Kabupaten Kutai Kartanegara. Jurnal Ilmu Pemerintahan. Kajian Otonomi Daerah, 1(1), 227-238.

Rohma, K. T. dan Ma'aruf, M. F. 2016. Pemanfaatan Alokasi Dana Desa Dalam Meningkatkan Pembangunan Infrastruktur Di Desa Bektiharjo Kecamatan Semanding Kabupaten Tuban,

Undang Undang Nomor 32 Tahun 2004 Tentang Pemerintahan Daerah (c.1) Jakarta, Direktorat Jenderal Otonomi Daerah.

Undang-Undang Republik Indonesia Nomor 6 tahun 2014 tentang Desa 